\title{
Mediterranean Urban Portraits: Thessaloniki and Izmir
}

Editorial note: The first part of the following text has been written as the position paper for the workshop on Mediterranean Urban Portraits (Thessaloniki and Izmir) organized by the Izmir Mediterranean Academy in Izmir on the 21st and 22nd October 2016. The second part of the text presents a collective preliminary report of the workshop.

"A Tale of Two Cities" in the Eastern Mediterranean: History of Thessaloniki and Izmir in 19th and 20th Centuries in Comparative Perspective

Alp Yücel Kaya* Dilek Akyalçın Kaya**

Port-cities of the Eastern Mediterranean, as studied very well in the literature, had common characteristics of economic and social development from the 19th century onwards. Yet, two of them, Thessaloniki and Izmir, as observed often by travelers and exchanged population, had more common characteristics than others, especially taking into consideration their social and urban texture.

Common trends of historical development of these two port cities in the 19th century Ottoman Empire could be described as such: Thessaloniki and Izmir had very rich hinterlands where commercial agriculture flourished from the middle of the 18th century onwards. As individuals increasingly searched for ways to curb controls and limits on production and trade throughout the Ottoman Empire, Izmir had emerged as the most important port in the Ottoman Empire's trade with the West and retained this position throughout the 19th century by carrying more than 50 percent of the Empire's exports. The volume of trade increased fourfold, exports threefold and imports sixfold between 184.0s and 1870s. Even more spectacular results apply to Thessaloniki. Within the same time span, Thessaloniki's export experienced a tenfold increase in the volume of trade, exports and imports. In the mid-19th century both port-cities started to establish their place synchronically within the world economy.

These developments in economic life resulted in the second half of the 19th century in both cities in infrastructural investments transforming urban space, such as the construction of railways connecting hinterlands to the ports and construction of new and larger ports to meet the requirements of increasing volume of trade. Commercialization of agriculture and subsequent construction of railways and ports led to capital

\footnotetext{
* Ege University, Department of Economics

** Izmir University of Economics, Department of Economics
} 
investments in urban industries first for consumption goods (i.e. flour mills) and then for capital goods (i.e. steam machines) with financial institutions and banking facilities emerging.

The demographic structure in each city changed completely during this period. In addition to the settlement of European entrepreneurs and seasonal fluctuations based on movement of migrant laborers from countryside, population grew, especially with the immigration resulting from successive wars, to feed meanwhile industrial labor force in the urban setting.

Such an economic transformation was hand in hand with the central and provincial administrative reforms aiming to administer the emerging world of economic interests. They included a reorganization of provincial administration, creation of local administrative and municipal councils. As a new administrative rationality was in formation, public spaces, buildings and transportation (places, parks, konak, caserne, tramway) took also their part in the new urban morphology of individual interests.

Flourishing commercial and industrial activities and new possibilities in administration created a need for qualified workforce in these sectors, hence the educational reforms. Public or private schools covering every level of education were opened by local initiatives.

The late 19th century was also marked by the emergence and multiplication of journals and magazines. These led to the emergence of different modes of expression and varied forms of sociability. Associations, societies and clubs became places where habitants participated to social life and political movements. Laborers whose number multiplied with the commercial and industrial growth and artisans who became more and more depressed with the intensification of capital in the urban space led the development of labor organizations and frequent emergence of strikes.

These transformations resulted in a qualitative change in the already existing social differentiation among habitants. In addition to artisans of economically fragile status, the new social configuration consisted of property holding bourgeoisie on the one hand, working laborers on the other had. This differentiation manifested itself within the urban structure of the city. The well-off habitants, or the ones who benefited most from these developments, started to gather in the newly founded quarters, (Hamidiye Mahallesi for Thessaloniki, Güzelyalı for Izmir) outside the city on the seaside. This movement from the center to new quarters turned out to be a manifestation of their belonging to a new city elite. High-ranking civil servants, foreign consuls, bank directors, industrialists, entrepreneurs, big merchants were part of the inhabitants of these new quarters.

On the other hand, fires, epidemics and brigandage became great fears of the emerging bourgeoisie and drove them to demand a healthier, safer, and a more secure environment. Local administration consisting 
of property holders was to establish and conserve the security of property and person vis-à-vis emerging urban poor or, as called, "classes dangereuses". The redefinition of the urban population on the basis of property holding and that of urban space on the basis of functional differentiation (business and habitation) were on the way in both port-cities.

Nevertheless, the story ended up in both cases with a conflictual, even ferocious, environment of social and political relations, between bourgeoisie and working poor on the one hand, within each of these segments of society on the other, in the era of an international turbulence. Central governments favored especially after the 1890 s some fractions of local bourgeoisie at the expense of some other fractions of the population of economically and politically fragile status... 1912 for Thessaloniki and 1922 for Izmir became historical turning points in the redefinition of political and social contexts in which both port-cities had to, henceforth, position themselves.

Conceived as preparatory meeting on the comparative analysis of urban societies of the Eastern Mediterranean in general, of Thessaloniki and Izmir in particular, the aim of this workshop is to gather scholars and researchers working on different aspects of Thessaloniki and Izmir in the 19th and 2oth centuries in order to discuss and forge themes and axes of research for a future symposium to be organized by the Izmir Mediterranean Academy. The discussion will be centered not only on common characteristics of the historical evolution, as exposed above, but also on particular characteristics of the historical evolution that these cities of particular political and economic contexts lived through from 19th to 2oth centuries. We plan to conduct the workshop around four main themes, being highly intertwined, with a comparative perspective: urban morphology, economic transformations, social relations and political movements. We argue that this thematic comparison will provide us a sound base onto which historical specificities; differences and similarities can be built. Doing this, we propose, will bring forward main features to be discussed about the transformation of urban societies of the Eastern Mediterranean during the 19th and 2oth centuries.

Main themes of the workshop evolution of urban morphology in Izmir and Thessaloniki in the 19th and 20th centuries; economic transformation of Izmir and Thessaloniki in the 19th and 20th centuries; individuals and social relations in Izmir and Thessaloniki in the 19th and 20th centuries; political movements and turbulences in the 19th and 20th centuries.

Participants of the workshop Uygur Kocabaşoğlu (Middle East Technical University, Izmir Mediterranean Academy), Elena Frangakis Syrett (New York City University), Alp Yücel Kaya (Ege University, Izmir Mediterranean Academy), Neslihan Ünal (Dokuz Eylül University), Erkan Serçe (Dokuz Eylül Univesity), Sibel Zandi-Sayek (William \& Mary University), 
Cana Bilsel (Middle East Technical University), Kalliopi Amygdalou (İzmir Institute of Technology), İrfan Kökdaş (İzmir Katip Çelebi University), Mathieu Jestin (Université Paris 1 Panthéon la Sorbonne), Paris Papamichos Chronakis (University of Illinois at Chicago), Dilek Akyalçın Kaya (İzmir University of Economics), Alexandra Yerolympos (Aristotle University of Thessaloniki), Yannis Epaminondas (Cultural Center of the National Bank of Greece Cultural Foundation in Thessaloniki), Ayșegül Sabuktay, Özgür Gökmen, Zeynep Gönen, Efthimios Maheras (Izmir Mediterranean Academy)

\section{Preliminary Report of the Workshop}

The workshop was conceived as a preparatory meeting on the comparative analysis of urban societies of the Eastern Mediterranean in general and of Thessaloniki and Izmir in particular. Since the 19th century, comparative research is not a novelty in the social sciences despite its rather rare practice. However, it has been challenged since 1990s by transfer studies on the one hand, and by connected/shared/entangled histories on the other without neglecting the critical standing of the histoire croisée approach towards all of these approaches. The aim of this workshop was to gather scholars and researchers working on different aspects of Thessaloniki and Izmir in the 19th and 20th centuries in order to discuss first the methodological framework of a comparative research on Mediterranean Urban Portraits and secondly forge themes and axes of research for a future symposium to be organized by the Izmir Mediterranean Academy. Lively discussion during the workshop resulted in five themes and axes of research for the future symposium:

\section{Port-cities as Movements, Circulations, Connections, and Networks}

Izmir and Thessaloniki, as port cities in the Eastern Mediterranean, are well connected both to their hinterlands and the external world. Indeed, they were also connected among themselves. There has been a continuous movement of goods, people, skills and ideas that frame their historical evolution. Their comparative and respective history could therefore be discussed especially by means of movements, circulations, connections and networks:

- Questions of "the infrastructures of mobility" arise in both cases; what are the means through which these movements, circulations, connections, and networks were operating/working? Mechanisms through which identities, skills, products, people, and ideas moved;

- Analysis of family networks that connected each port city to the outside world (or just Izmir and Thessaloniki) would be revelatory; 
- Study of regionalization/re-regionalization taking into account clusters of movements, circulations, connections and networks as opposed to the study of center (Istanbul)-periphery (port-city) relationships;

- Analysis of the relationship between the port-city and its hinterland, the comparison of this relationship and hinterlands (Macedonia vs. Asia Minor);

- Examination of territorialization of port-cities and the Mediterranean with respect to clusters of movements, circulations, connections and networks in the making;

- Investigation of a relational perspective between port-cities on the one hand, and between inland port-cities and island port-cities on the other;

- Reappraisal of world-system analysis on port-cities especially by questioning the causality that runs from external markets to the port-cities;

- $\quad$ Fluidity of borders, be it geographic (city-hinterland, MediterraneanLevant, etc.) or identities (ethnic, religious, etc.).

\section{Political Scene in the Port-Cities}

- Development and/or the construction of a city identity, citizenship, was noticeable in Thessaloniki in the turn of the 2oth century; what about in Izmir?

- Comparative analysis of the Chamber of Commerce that became, in both cities, an arena where different economic and political interests were displayed;

- Comparative analysis of institutions, such as consulates as local actors holding not only vertical relationships with external world but also horizontal relationships with different groups of the city population;

- To question agency of central state and the degree of autonomy of port-cities vis-à-vis the central state;

- Comparative study on the preliminary events and resulting effects of the Revolution of 1908 in both cities;

- Political conflicts among different groups of population should not be underestimated when studies favor interactions and connections within and outside the port-cities;

- The relational comparison of the two port-cities in their respective politics, especially in the nation-state formation;

- How nationalisms spoke to each other, how actors, populations contributed to/changed the politics when they moved from one city to the other. 


\section{Urban Redesign/Transformation in the Port-Cities}

- What are the factors of change in the urban design?

- The comparative analysis on fortification that both cities had;

- The comparative analysis on the construction of quays and railroads;

- The comparative analysis on the extension of quarters;

- The morphological, social and political effects of big fires in the urban re-design;

- The study of "ferhane/frenkhane"s in the case of Izmir;

- The comparative analysis of urban plans of Izmir and Thessaloniki, especially in terms of the effects of modern urban planning approaches.

\section{Urban Classes: Making of Bourgeoisie and Working-class in the Port-Cities}

- The study of urban classes not from the perspective of exchange relations but from that of production relations, i.e. capital-labor or employer-worker;

- The study of classes in the making from the 18th century onwards to the 2oth century;

- The analysis of social differentiation and conflicts in which production relations and the formation process of social classes resulted;

- The analysis of migration framing the formation of social classes, especially that of urban working-classes; the continuous character of migration from/to hinterland in both cases, from/to Aegean Islands in the case of Izmir;

- The study of the presence of "foreigners" in port-cities and the transformation that they lived through during centuries with respect to their changing economic and social role;

- The analysis of the Chamber of Commerce that became, in both cities, an arena where different economic and political interests were displayed;

- The study of agency of different urban groups (such as entrepreneurs), their relation to the city, their self-perception in relation to the city and their definition by others.

\section{Wars: Balkan Wars, WWI, Greek Occupation; Interwar Period}

- The economic, social and political life in Izmir during the Greek occupation period;

- The de-urbanization during and re-urbanization after the war. 
The discussion during the workshop privileged not only these themes but also underlined some points to be considered as general remarks:

Limitation and potentialities of sources: who produced sources (documents, maps, plans, etc.), for what reason? Discrepancy of sources; lack of sources;

Relativity of scale: thinking port-cities under a multilayered (interdependent/independent) scale: local-national-global; not prioritizing one over the other but looking at especially those layers that have been neglected;

The questions of comparative method for examining the portcities: the need to find relations and encompassing comparisons rather than taking them as isolated units. What can one case tell us about the other, what questions can the studies on one city can help pose for the other city? The comparative thinking rather than the comparative analysis;

The making of port-cities: the importance of process, analysis from 18th century onwards; integration of small port-cities and islands into the discussion;

The port-city does not only depend on trade: the prominence of the life of entertainment in the port-cities is noticeable; trade and life of entertainment went hand in hand.

The development of collective memories (of glorious and prosperous days) of the exchanged populations on the one hand, and the contestation of memories on the other (appeal to oral history); plurality of memories;

\section{The future symposium would be based on}

- presentation of the state of the field in Turkish and Greek?

- exchange of points of view?

- presentation of new sources?

- presentation of new knowledge/research in a comparative and/ or relational manner?

The future symposium would be accompanied with expositions of maps, plans, postcards, photos?

Workshop reporters Alp Yücel Kaya, Dilek Akyalçın Kaya, Zeynep Gönen, Efthimios Maheras 